\title{
Discussion: Cracks in steel structures
}

Allan P. Mann CEng, FREng, FIStructE, MICE Senior Consultant, Jacobs, Manchester, UK
Ian Hulme

Technical Leader, Transmission, Beca

\section{Contribution by I. Hulme}

The paper by Mann (2011) did not comment on whether there is possible degradation of properties or deterioration of aged steel. Specifically, is geriatric steel as strong, tough and so forth as new steel and, if not, then what to do? The contributor is aware that problems regarding failure of members in tension in lattice steel transmission towers of non-killed steel have been experienced in Germany. Is there an issue and, if so, is it restricted to certain types of manufacture, non-killed steel and so on? This is important in many fields of engineering but especially so in power transmission where many steel structures, some of around 100 years of age, are being reviewed for additional loading and upgrading.

\section{Author's reply}

There should not be any degradation of fundamental strength or toughness properties over time. Nevertheless, as a generality, it is to be expected that very old steels might have less consistent properties simply because modern manufacturing techniques are much improved. Moreover, 100 years ago, the importance of toughness as a material property was not as well appreciated as it is now. Toughness is the property that assures resistance against brittle fracture types of failure and the risk factors are use of steel with low intrinsic toughness, tensile stress and cracks. The risks are exacerbated when the steel is cold because of the lowering of steel toughness with temperature.

Fracture problems are traditionally associated with welded structures because they provide a crack (albeit at microscopic level) and a high residual tensile stress and a potential hardness (embrittlement). Lattice transmission towers do not normally have welded joints, but they do operate in very cold temperatures and may have very high tensile stresses from wind action. There is a possibility, perhaps remote, of fatigue cracking from wind action plus the possibility of microcracking around holes that have been punched (say, through angles). The relatively small dimensions of tensile members may be an issue as cracks of even modest length might propagate enough to cause gross reduction of cross-sectional area and complete failure before detection.

Clearly, basic steel toughness is an issue and a steel's toughness is affected by its chemistry and manufacturing route. To gain a beneficial small grain size, it is desirable to use steel deoxygenated with aluminium and normalised. 'Killed' steels are hence advantageous. On the other hand, the steel used in angles for transmission towers is normally 'thin', which is beneficial in reducing toughness demands (but it is that same thinness that permits the forming of holes by punching). Overall, the risk factors of cracking (from punching), tensile stress (amplified at stress concentrations, around holes for example), potential lack of material toughness and operation in very low temperatures all seem to co-exist. That might explain some of the failures.

\section{REFERENCE}

Mann A (2011) Cracks in steel structures. Proceedings of the Institution of Civil Engineers - Forensic Engineering 164(1): 15-23, http://dx.doi.org/10.1680/feng.2011.164.1.15.

\section{WHAT DO YOU THINK?}

To discuss this paper, please email up to 500 words to the editor at journals@ice.org.uk. Your contribution will be forwarded to the author(s) for a reply and, if considered appropriate by the editorial panel, will be published as discussion in a future issue of the journal.

Proceedings journals rely entirely on contributions sent in by civil engineering professionals, academics and students. Papers should be 2000-5000 words long (briefing papers should be 1000-2000 words long), with adequate illustrations and references. You can submit your paper online via www.icevirtuallibrary.com/content/journals, where you will also find detailed author guidelines. 